\title{
Problems and Prospects of Poultry Rearing in Lagelu Local Government Area of Oyo State, Nigeria
}

\section{*FADIMU, BO; AKINYEMI, IG; OGUNDIMU, OA; LAWAL, MO; ADEYOMOYE, GA; AKINLABI, TJ}

\author{
Department of Wildlife and Ecotourism, Forestry Research Institute of Nigeria, Forest Hill, Jericho, P.M.B. 5054, Ibadan, Oyo State, \\ Nigeria \\ *Corresponding Author Email: fadimubabatunde@gmail.com; Tel: +2348032817948
}

\begin{abstract}
World poultry production is increasing yearly yet the demand for the products has not been met. This study assessed the problems and prospects of poultry rearing in Lagelu Local Government Area of Oyo State, Nigeria. The study was carried out among poultry farmers with interview schedule of Eighty (80) farmers using structured questionnaires. The study examined social characteristics of poultry farmers, benefits of poultry production, needs and constraints of poultry production in the study area. Descriptive statistical analysis was used to analyze data. The study revealed that $73.80 \%$ of the respondents were males and $26.20 \%$ were females, $52.60 \%$ had tertiary education, $36.20 \%$ had secondary school education and $11.20 \%$ had primary school education. The result showed that $67.50 \%$ of the respondents had increase in egg production, $15.00 \%$ had average increase in egg production and $17.50 \%$ had no increase in egg production. The respondents had maximum income benefit with $15.00 \%$ always having high income, $51.20 \%$ low income and $33.80 \%$ indicated indifference in their income. In this research work, the poultry farmers shows various needs to boost their production, where $91.20 \%$ have problems of good storage facilities, $92.50 \%$ with problems of pest and disease control, $88.80 \%$ request for training for farmers and $53.8 \%$ aimed at credit facilities. The major problems that poultry farmers encounter in the study area are inadequate capital $(100.00 \%)$, pest and disease $(100.00 \%)$, lack of credit facilities $(100.0 \%)$ and high cost of feeding $(80.0 \%)$ of the respondents.
\end{abstract}

\section{DOI:https://dx.doi.org/10.4314/jasem.v24i9.14}

Copyright: Copyright (C) 2020 Fadimu et al. This is an open access article distributed under the Creative Commons Attribution License (CCL), which permits unrestricted use, distribution, and reproduction in any medium, provided the original work is properly cited.

Dates: Received: 10 August 2020; Revised: 16 September 2020; Accepted: 22 September 2020

Keywords: Poultry, production, farmers, problems, constraints

Poultry are domesticated birds kept by humans for their eggs, meat and feathers. Reasonable numbers of these birds are typically members of the suborder Galloanserae (fowl), especially the order Galliformes (which includes chickens, quails, and turkeys). The poultry sector offers the quickest returns to investment outlays in livestock enterprise by virtue of its short gestation period, high feed conversion ratio alongside being one of the cheapest, commonest and best sources of animal protein in the country (Ojo, 2002). Nigeria's poultry industry has its root in the initiative of regional governments from the 1960's when the Western Regional Government entered into joint pilot poultry production schemes with some foreign partners, notably the Israeli government (Adene and Oguntade, 2006). The entry of private investors into poultry production in the late 1960 s to early 1970 s marked the onset of indigenous commercial poultry industry. It then spread from the west to the eastern region and parts of the Northern region with the west especially witnessing tremendous growth (Adene and Oguntade, 2006).According to the
Food and Agricultural organization of the United Nations (FAO), more pork is eaten in the world than any other terrestrial meat(FAO, 2013). About $37 \%$ of all meat consumed in the world is pork (110 million metric tonnes, $\mathrm{mmt})$ - ahead of beef $(67 \mathrm{mmt})$ and chicken $(104 \mathrm{mmt})$. The size of the industry grew from less than 1million in the mid-1960s to over 40 million by the early parts of the 1980s. All along, the growth of the industry had been propped on by government initiatives and incentives especially in terms of training, technological support, input support services and others. Adene and Oguntade, (2006) assert that many of the poultry technical staff were products of government subsidizing training programs, although inputs like vaccines and diagnostic services were either subsidized by government or even given out freely at the initial stage. The meat and egg from poultry are good source of animal protein which is essential in the maintenance of the body growth and the repair of worn out tissues, thus making poultry and its products an important dietary food. Chicken meat and eggs provide not only high quality protein, but 
also important vitamins and minerals. To have a successful poultry production, ration with which the birds are fed must be well formulated with all nutrient classes in exact quantity and quality for specific age for the birds to meet their nutritional requirements. Vitamins and minerals are two distinct groups of compounds that perform a variety of functions in the animal body, but for poultry they are usually considered together and are simply put as premixes.

However, despite the growing population of commercial poultry, the subsistence and the small scale units are still prevalent all over sub-urban areas, rural places and especially in the villages. Although the commercially oriented poultry pens are abundant all over the state with varying modern scientific approaches to production of poultry, yet output continue to be inadequate and prices increasing above the reach of a common man. Poultry production as an aspect of livestock production is important to the biological needs, economic growth and social development of the people in any nation (Oladeebo and Ambe-Lamidi, 2007). However, the contribution of poultry production (meat and eggs) to total livestock output increased from $26.0 \%$ in 1995 to $27.0 \%$ in 1999 with an increase in egg production alone accounting for about $13.0 \%$ during the period (Ojo, 2003).

Despite the acknowledged importance of poultry production, the industry is still characterized by low production level due to limited finance for the procurement of basic poultry equipment and materials (Akanni, 2007).The result of this is that many of the small-scale poultry farmers are not encouraged to increase their productivity; thereby progressing from small-scale production to large scale production by farmers is hindered which could be detrimental to the rate of increase of the industry.

\section{MATERIALS AND METHOD}

Study Area: This study was carried out in Lagelu Local Government Area of OyoState, Nigeria. Its headquarters is situated at Iyana Offa. Lagelu local government area is subdivided into 14 wards: Ajara/Opeodu, Apatere/Kuffi/Ogunbode/Ogo, ArulogunEhin/Kelebe, Ejioku/Igbon/Ariku, Lagelu Market/Kajola/Gbena, Lagun, Lalupon I, Lalupon II, Lalupon III, Ofa-Igbo, Ogunjana/Olowode/Ogburo, Ogunremi/Ogunsina, Oyedeji/Olode/Kutayi, Sagbe/Pabiekun.It has over 1076 towns and villages including the principal towns ofOlorunda, Lalupon, Lagun, Monatan, Apatere, Ofa, Ejioku, Oyedeji, Kelebe, Sagbe, Elegbaada, Wofun, Ogburo, Kutayi, Ogunjawa, Ile-Igbon, Iyana Church, Odo Oba, Sukuru, Akinsawe and Olowode.
It has an area of $338 \mathrm{~km}^{2}$ and a population of 147,957 at the 2006 census (NPC, 2006). The main occupation of the people in this local government area is farming including large production of palm oil and black soap; thus the thriving of traditional palm oil and soap making industries.

Sampling Procedure and Sample Size: Random sampling technique was used to carry out this research work. A total number of 120 structured questionnaires were distributed and 80 were retrieved.

Data Collection: Well-structured questionnaires and personal interview of poultry farmers was used for primary data collection. The content of the questionnaire was open and close ended questions.

\section{RESULTS AND DISCUSSION}

The socio economic characteristics of poultry farmers in the study area is as presented in Table1. The result showed that $73.80 \%$ of the respondents were males while $26.20 \%$ were females. This shows that poultry production in the study area was dominated by men; this may be as a result of an extra effort in making additional income to cater for the family (Salum et al., 1999). However, poultry rearing serves as a good subsidiary occupation that supplements the income of smallholder farm families and rural households in most developing countries (Anang et al., 2013). The result indicates that the age distribution of the respondents within the range of 20-39 years has $81.30 \%$ of the total, which showed that most of the farmers were agile to carry out the production activities as age is a factor to be considered with labour required for the production process. $52.60 \%$ of the respondents had tertiary education and this could improve the ability of the farmers to carry out careful observation and access information through technology, complying with Amos (2006) who stated that education is important for the abduction of new innovations. Level of education has significant impacts on poultry production through the various management activities carried out on the farm. Education has been described as being pivotal to unlocking the entrepreneurial abilities of farmers and enhancing their ability to understand and evaluate new production techniques (Obasi, 1991; Iheke, 2010; Nwaru et al., 2011).Lastly, the result showed that the farmers had good experience that is well above 11 years representing $66.30 \%$ of the total respondent. The number of years of experience in poultry production helps the farmers to increase their potentials to cope with risk involved with the production. According to Nwaru et al. (2011), the number of years a farmer has spent in the farming business may give an indication of the practical 
knowledge he has acquired on how he can overcome certain inherent farm production problems.

Table 1: Socio economic characteristics of poultry farmers in the

\begin{tabular}{|c|c|c|}
\hline Variables & Frequency & Percentage $(\%)$ \\
\hline \multicolumn{3}{|l|}{ Gender } \\
\hline Male & 59 & 73.80 \\
\hline Female & 21 & 26.20 \\
\hline Total & 80 & 100.00 \\
\hline \multicolumn{3}{|c|}{ Age (Years) } \\
\hline $20-29$ & 19 & 23.80 \\
\hline $30-39$ & 46 & 57.50 \\
\hline $40-49$ & 15 & 18.80 \\
\hline Total & 80 & 100.00 \\
\hline \multicolumn{3}{|c|}{ Marital Status } \\
\hline Single & 21 & 26.20 \\
\hline Married & 56 & 70.00 \\
\hline Divorced & 3 & 3.80 \\
\hline Total & 80 & 100.00 \\
\hline \multicolumn{3}{|c|}{ Educational Background } \\
\hline Primary & 9 & 11.20 \\
\hline Secondary & 26 & 36.20 \\
\hline Tertiary & 42 & 52.60 \\
\hline Total & 80 & 100.00 \\
\hline \multicolumn{3}{|l|}{ Religion } \\
\hline Christian & 65 & 81.20 \\
\hline Islam & 15 & 18.80 \\
\hline Total & 80 & 100.00 \\
\hline \multicolumn{3}{|c|}{ Experience (Year) } \\
\hline $1-10$ & 27 & 33.80 \\
\hline $11-20$ & 38 & 47.50 \\
\hline $21-30$ & 15 & 18.80 \\
\hline Total & 80 & 100.00 \\
\hline \multicolumn{3}{|c|}{ Do you engaged in poultry production } \\
\hline Yes & 80 & 100.00 \\
\hline No & 0 & 0.00 \\
\hline Total & 80 & 100.00 \\
\hline
\end{tabular}

Table (2) showed that there was a marked increase of $67.50 \%$ in egg production and a decrease of $15.00 \%$. Availability of drugs was considered to be $45.00 \%$ high, $25.00 \%$ low and an indifference percentage change of 30.00 . Diseases remain one of the major threats to boosting poultry production in Nigeria (Adewole, 2012). The income generated by the farmers was considered and the values recorded were $15.00 \%$ increase, $51.00 \%$ decrease and $33.80 \%$ indifference. The result showcased poultry as a low income generation business and a likely discouragement to new investors. This is consistent with the study of Adekanye (2000) who stated that every investor is looking to maximize profit in any set up of its entrepreneur. In general, every business enterprise aims at greater productivity to ensure continuous survival and growth of the industry. Furthermore, the result showed that $30.00 \%$ of the respondents had an increase in their standard of living through the business, $46.20 \%$ with a decrease and $23.80 \%$ having indifference. It was also indicated that $36.20 \%$ of respondents agreed that there was increase in meat product and $41.20 \%$ with a decrease while
$22.50 \%$ recorded indifference. This implied that there was increase in meat production in the study area. Household nutrition and food security is strongly supported by availability of poultry in the household (Sonaiya, 2007).

Table 2: Benefit of poultry production inputs

\begin{tabular}{llll}
\hline Variables & High (\%) & Low (\%) & Indifferent (\%) \\
\hline Increase in egg production & $54(67.50)$ & $12(15.00)$ & $14(17.50)$ \\
Poultry production training & $45(56.20)$ & $17(21.20)$ & $18(22.50)$ \\
Availability of drug & $36(45.00)$ & $20(25.00)$ & $24(30.00)$ \\
Farm implement & $35(43.80)$ & $24(38.00)$ & $21(26.20)$ \\
Availability of labour & $28(35.00)$ & $35(43.80)$ & $17(21.20)$ \\
Demand and supply & $32(40.00)$ & $32(40.00)$ & $16(20.00)$ \\
Production resources & $27(33.80)$ & $34(42.50)$ & $19(23.80)$ \\
Maximum income & $12(15.00)$ & $41(51.20)$ & $27(33.80)$ \\
Increase in standard of living & $24(30.00)$ & $37(46.20)$ & $19(23.80)$ \\
Increase in meat production & $29(36.20)$ & $33(41.20)$ & $18(22.50)$ \\
\hline
\end{tabular}

Filed survey: 2019

Table 3 shows the needs assessment of the respondent in the study area where majority of them $(53.80 \%$ and $22.50 \%$ ) agreed that loans and credit facility should be made available to them in the study area. A productive resource such as agricultural credit is very vital for efficient and sustainable production activities especially in developing countries (Nweke, 2001). In a bid to avoid losses and increase productivity, $65.00 \%$ of the respondents strongly agreed that readily available markets should be provided for their products. Dolberg (2013) lamented that: "Limited Access to the Core Markets" is the major problem of the industry. $82.50 \%$ of strongly agreed and $17.50 \%$ of the respondents agreed that adequate electricity will allow them preserve their products through good storage facilities. The need for storage in the country is a necessary tool which helps farmers to preserve their farm produce and products from wastage thereby reducing loss. Majority $(71.20 \%)$ of the respondent strongly agreed that new technologies on rearing of poultry birds will help them to increase in productivity while $16.20 \%$ only agreed with the statement. It was shown that majority of the respondent strongly agreed that prevention of disease is one of the major needs in the study area, while $91.20 \%$ strongly agreed that storage facilities is their needs in the study area. FAO (2001) indicated that disease and pests need to be minimized in livestock production in Nigeria. The table 4 indicates the problems faced by poultry farmers in the study area where $80.00 \%$ of respondent agreed that the cost of feeds and feeding is their major problem and $20.00 \%$ agreed that feeding is a minor problem. All of the respondents $(100.00 \%)$ declared that capital is a great challenge been faced by the farmers in the study area and they all agreed that capital determines the size of your farm and how a farm is equipped. Amount of capital will determine the size of a farm, access to capital determines the growth 
rate of farms and how equipped a farm will be. Odoh et al., (2009) reported that "farm credit is among the essential factors needed for agricultural production, and with it, farmers can secure farm inputs such as; farm equipment and hired labour. The result indicate that $33.80 \%$ of the respondents agreed that labour is a major problem while $53.80 \%$ agree that labour is a minor problems, also that problem of pests and diseases are major problems in the study area which agrees with Adewole (2012) stating that diseases remains one of the major threats to boosting poultry production in Nigeria. According to Akpabio et al.
(2007) that the major factor that determines the breakdown of any livestock farming is disease and it must be considered by individual farmer and government should help the farmers in combating the challenges. It was revealed that $65.00 \%$ of the respondents agreed that marketing is a problem in the study area and the entire respondents $(100.00 \%)$ agreed that high cost of medication and lack of credit facilities is a great challenge., (Ahmed , 2013) stated that marketing is problem that determine the profit level of any business setup.

Table 3: Needs assessment of poultry farmers in the study area

\begin{tabular}{|c|c|c|c|c|}
\hline Variables & $\begin{array}{l}\text { Strongly } \\
\text { agree } \%\end{array}$ & Agree $\%$ & $\begin{array}{l}\text { Disagree } \\
\%\end{array}$ & $\begin{array}{l}\text { Strongly } \\
\text { disagree \% }\end{array}$ \\
\hline Loan and credit facilities & $43(53.80)$ & $18(22.50)$ & $5(6.20)$ & $14(17.50)$ \\
\hline Provision of farmers market & $52(65.00)$ & $18(22.50)$ & $5(6.20)$ & $5(6.20)$ \\
\hline Power supply & $66(82.50)$ & $14(17.50)$ & & \\
\hline Provision of government policy & $60(75.00)$ & $16(20.00)$ & $4(5.00)$ & \\
\hline Good source of information & $56(70.00)$ & $15(18.80)$ & $9(11.20)$ & \\
\hline Training for the farmers & $71(88.80)$ & $9(11.20)$ & & \\
\hline Access to market information & $57(71.20)$ & $13(16.20)$ & $10(12.50)$ & \\
\hline Information on new technology of poultry rearing & $57(71.20)$ & $13(16.20)$ & $10(12.50)$ & \\
\hline Prevention of disease & $74(92.50)$ & $6(7.50)$ & & \\
\hline Access to good storage facilities & $73(91.20)$ & $7(8.80)$ & & \\
\hline
\end{tabular}

Table 4: Constraints facing poultry farmers in the study area

\begin{tabular}{llll}
\hline Variables & Major & Minor & Not at all \\
\hline High cost of feeds & $64(80.00 \%)$ & $16(20.00 \%)$ & \\
High mortality & $54(67.50 \%)$ & $26(32.50 \%)$ & \\
Inadequate capital & $80(100.00 \%)$ & & \\
Lack of technical known how & $44(55.00 \%)$ & $36(45.00 \%)$ & \\
Labor supply & $27(33.80 \%)$ & $43(53.80 \%)$ & $10(12.50 \%)$ \\
Disease and pest & $80(100.00 \%)$ & & \\
Marketing problems & $52(65.00 \%)$ & $28(35.00 \%)$ & \\
Poor weather & $55(68.80 \%)$ & $25(31.20 \%)$ \\
High cost of medication & $80(100.00 \%)$ & \\
Lack of credit facilities & $80(100.0 \%)$ & \\
\hline \multicolumn{4}{c}{ Filed survey: 2019} \\
\end{tabular}

Conclusion: The age range of poultry farmers in the study area was in the bracket of productive age for human, it is an advantage to the production output in the study area. From the analysis of information gathered in this study, it is obvious that poultry production has a great potential in bridging animal protein gap, create employment for the for people in the study area, generate sufficient income for the poultry farmer and increase food security in our society.

In providing solutions to the problems of poultry farmers in Lagelu local government area, it will be recommended that government in all arms and private bodies should intervene in provision of good credit facilities to the poultry farmers, subsidize the cost of feeds and feed ingredients, create access to ready markets, provide good electricity, provide veterinary centers and veterinary personnel for the poultry industry in the study area.

\section{REFERENCES}

Adekanye, T.O. (2000). Readings in Agricultural Marketing. Longmans Nigeria Limited, 215pp.

Adene, D.F. and Oguntade, A.E. (2006). The structure and importance of the commercial and rural based poultry industry in Nigeria. Nigerian Poultry Sector Report, FAO (Rome) study. http://www.fao.org/docs/eims/upload//214281/Revie w Nigeria.

Adewole, S.O. (2012). The efficacy of drugs in the treatment of coccidiosis in chicken in selected poultries. Acad. Res. Int., 2: 20-24.

Ahmed, A. and Ahmad, A.K. (2013). Economic Analysis of Poultry (Broiler) Production in Amman and Irbid District in Jordan. Inter. J. Life Sci. Res. 1 (1): 24-30. 
Akanni, I.A. (2007). Effect of Micro-Finance on Small Scale Poultry Business in SouthWestern Nigeria. Emirate J. Food. Agric. 19(2): 38-47.

Akpabio, 1.A., Okon, D. P., Angba, A. O. and Aboh, C. L (2007). Avian Influence Scare and the Poultry Egg Production in Uyo Urban, Nigerian. Inter. Journal Poultry Sci.6: 298-301.

Amos, T.T. (2006). Analysis of backyard poultry production in Ondo state, Nigeria. Int. Jour. Poult. Sci., 5: 247-250.

Anang, B. T., Yeboah, C. and Agbolosu, A. A. (2013). Profitability of Broiler and layer production in the Brong Ahafo region of Ghana. J. Agric. Biol. Sci. 8(5) 423-430.

Dolberg, F. (2013). Review of Household Poultry Production as a Tool in Poverty Reduction with Focus on Bangladesh and India. FAO, Pro-Poor Livestock Policy Initiative, working paper No.6.

FAO and World Bank (2001). Farming system and poverty improving farmer's livelihood in a changing World. Rome and Washington D.C.

Food Outlook.FAO, (2013). Available online: http://www.fao.org/docrep/012/ak341e/ak341e09. htm\#TopOfPage (accessed on 14 May 2013).

Food Outlook.FAO, (2013). Available online: http://www.fao.org/docrep/012/ak341e/ak341e09.

http://www.oyostate.gov.ng/local-governments/oluyolelocal-government/ciwf.org.uk" compoassion in world farming-meat chickens-welfare issues". Retrived 2011-08-26.https://en.wikipedia. rg/wiki/Lagelu, Oyo

Iheke, O. R. and Nwagbara, C. (2010). Comparative Analysis of the Profitability in Brood and Sell and Brood and Finish Broiler Enterprises in Abia State of Nigeria. Inter. J. Agric. Rural Develop. 13(2): $340-$ 345 .

James, R. G. and Frank, B. F. (2010). Modern Livestock and Poultry Production. Cengage Learning. p. 693. ISBN 978-1-4283-1808-3. Retrieved 7 November 2012. Post Offices- with map of LGA. NIPOST. Archived from the original on 2012-11-26. Retrieved 2009-10-20.

NPC (2006). Nigeria National Population Commission. Census Report.http://www.population.gov.ng/.

Nwaru, J. C., Iheke, O. R. and Onyenweaku, C. E. (2011). Impact of Migrant Remittances on the Welfare of Arable Crop Farm Households in South Eastern
Nigeria. Human Ecology Review, Vol 18 (2): 159166.

Nweke, N. O. (2001). Farming in Rural Areas. Satellite Newspapers. Office of Human Resources and Development. Pp. 25-31.

Odoh, N. E., Nwibo, S. U and Odom, C. N. (2009). Analysis of Gender Accessibility Of Credit By Smallholder Cassava Farmers In Afikpo-North Local Government Area Of Ebonyi State. Nigeria Continental J. Agricultural Economics, 3: 61 -64.

Obasi, P. C. (1991). Resource Use Efficiency in Food Crop Production: A Case Study of the Owerri Agricultural Zone of Imo State, Nigeria. M.Sc Thesis, University of Ibadan, Ibadan, Nigeria.

Ojo, S.O.(2002). Analysis of the three risk factors in commercial poultry production in Osun State, Nigeria. Proceedings of the 27th Annual Conference of Nigeria Society for Animal Production, March 1721, 2002, Federal University of Technology, Akure, Nigeria.

Ojo, S.O. (2003). Productivity and technical efficiency of poultry egg production in Nigeria. Int. J. Poult. Sci., 2: 459-464.

Oladeebo, J.O; Ambe-Lamidi, A.I. (2007). Profitability, Input Elasticities and Economic Efficiency of Poultry Production among Youth Farmers in Osun State, Nigeria. Inter. J. Poultry Sci. 6: 994-998.

Rahji, M.A.Y. and Fakayode, S.A. (2009). A multinomial logit analysis of agricultural credit rationing by commercial banks in Nigeria. Inter. Res. J.Finance and Economics, 24:91.

Salum, M.R., Mwamuhehe, H.A. Mtambuki, A.B. and Mwihumbo, A. (1999). Report of the informal survey on village chickens in Southern Tanzania. Report of the First Internal Program Review of the Tanzania Agricultural Research Project (TARP II), Naliendele, Mtawara, Tanzania (cited from Buza and Mwamuhehe, 2001).

Smith, A. J. (2001). Poultry in context. The Tropical Agriculturist CTA.1-63.

Sonaiya, E.B. (2007). Family poultry, food security and the impact of HAPI. World's Poultry Sci. J. 63(1):132- 138 . 